\title{
Maltese chert: An archaeological perspective on raw material and lithic technology in the central Mediterranean
}

\author{
Huw S. Groucutt $1,2,3$ \\ ${ }^{1}$ Extreme Events Research Group; Max Planck Institutes for Chemical Ecology, the Science \\ of Human History, and Biogeochemistry, Jena, Germany. \\ ${ }^{2}$ Department of Archaeology, Max Planck Institute for the Science of Human History, Jena, \\ Germany. \\ ${ }^{3}$ Institute of Prehistoric Archaeology, University of Cologne, Cologne, Germany.
}

\begin{abstract}
The Maltese islands are renowned for their prehistoric archaeological record, particularly the famous megalithic 'temples' and associated ceramics and artwork. The temples were built by a society lacking metal technology, who relied on stone and organic materials. Knapped stone tool (lithic) technology, to produce sharp edged tools for tasks like cutting, hide working, and wood shaping involved the use of both imported obsidian and high-quality chert - offering insights into themes of exchange and connectivity - and local chert. The local chert has generally been described as low-quality, yet relatively little research has been conducted on its distribution, characteristics, and use. In this paper I report a survey of chert sources, identifying a wider distribution of chert outcrops along the west coast of Malta than previously discussed. Some general macroscopic properties are outlined, while there are also aspects of variability in the chert sources. Knapping experiments were then conducted on samples of chert collected, allowing clarification of its characteristics. These observations are used to offer some insights into lithic technology in Neolithic and Temple Period Malta, such as the hypothesis that the high frequencies of multidirectional flake production and subsequent 'scraper retouch' reflect adaptations to the characteristics of local chert.
\end{abstract}

Keywords: Malta, stone tools, knapping, prehistory. 


\section{Introduction}

The Maltese archipelago in the central Mediterranean has a justifiably famous archaeological record. As Renfrew (2004, p.10) put it, "for the prehistorian Malta is one of the most remarkable places on earth". UNESCO World Heritage Sites such as Tarxien, Hagar Qim, Mnajdra, and Ggantija temples reveal spectacular megalithic architecture, and a wealth of finds such as diverse pottery and various figurines and statues (see e.g. Trump 1966, 2002; Evans 1971; Malone et al. 2009a, 2020b; Sagona 2015; Bonanno 2017; French et al. 2020, among many others). For thousands of years, until the transition to the Bronze Age around $2000 \mathrm{BC}$, people in Malta did not use metal, so understanding stone and organic technologies is crucial to elucidating early Maltese societies.
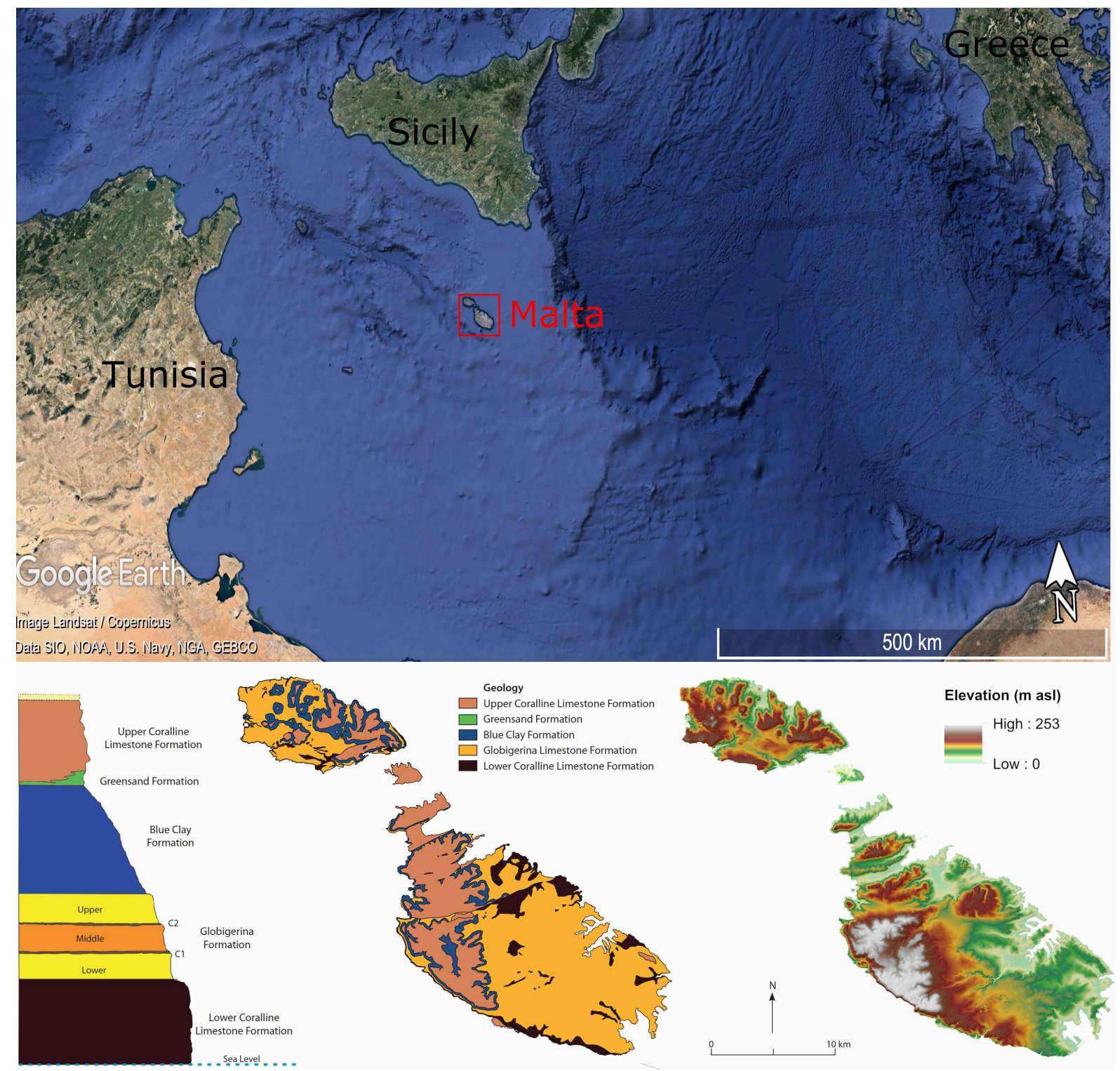

Figure 1. The location, geology and topography of the Maltese Archipelago. (Bottom left and central images reproduced from P. Chatzimpaloglou et al. (2020a, 22), CC-BY-ND licence. Bottom right image reproduced from Alberti et al. (2018, 3), CC-BY-4.0 license). 
In this paper I investigate Maltese Neolithic and Temple Period stone tool technology in the sense of knapped (flaked) stone, where rocks with particular fracture properties were shaped and struck to produce sharp-edged flakes. Flakes (including elongated forms, called blades) may be modified by further small flaking of the edges ('retouch') to produce different sized and shaped tools. The earliest stone tools were made over three million years ago (Harmand et al.2015), and stone tools provide the overwhelming majority of evidence for human behaviour until the last few thousand years. Stone tool technology illuminates early human society in a variety of ways: from how the raw material was transported, to how culturally inherited ways in which cores (nodules of rock) were shaped to produce sharp flakes of particular forms, through to how tools were used and abandoned. Understanding how ancient people in Malta were connected to neighbouring societies, how their behaviour changed over time, the nature of their subsistence, how they produced artwork and megalithic architecture, and many other things will all be illuminated by understanding the stone tool technology that people used.

\section{Maltese lithic technology}

Stone tools have long been recognised in the Maltese archaeological record (e.g. Ashby et al. 1913; Zammit 1930; Trump 1966; Evans 1971). Trump (1966, 29), for instance, commented that at Skorba, lithics were abundant, and indeed that several layers produced "more flakes than potsherds". It is only in recent years that detailed work on Maltese lithic assemblages has begun to be conducted. Studies of Maltese lithic assemblages are reported by Malone and colleagues (2009b, 2020b), from sites such as the Xaghra Circle, Santa Verna, and Tać-Cawla, all of which have produced hundreds of stone tools. Vella (2008a, 2008b, 2009, 2011a, 2016) reports on lithic assemblages from several sites, such as Ta' Hagrat (Vella, 2009). While most assemblages are from temples and other seemingly ritual sites, there are also insights from the wider landscape, with, for instance, extensive surface surveys in central Gozo identifying hundreds of lithics (Grima et al. 2020).

While most analyses have focussed on typological classification, some technological characteristics are clear. In terms of core reduction methods, there is a general focus on flake, rather than blade, production. Vella (2009) for instance emphasises multidirectional flaking, and the "largely expedient and informal" character of Maltese lithic technology (Vella 2011a). Likewise, Vella $(2016,10)$ described the "largely expedient" character of local chert reduction, "with no sign of unidirectional knapping and suggestive of a relatively informal production process". It is also worth pointing out that this "expedient and improvised character" seems to not only characterize the local chert, but also imported chert and obsidian (Moscoloni and Vella 2012). There is, however, sometimes a blade component to the assemblages (e.g. Trump 1966; Malone et al 2009b, 2020b), both on local chert and with other raw materials (figure 2). The recent suggestion that there is Levallois technology in the Maltese assemblages (Chatzimpaloglou 2019) seems to be a case of mistaken identity, based on the images provided. From published reports on Maltese lithic assemblages, a consistent feature is the paucity of cores, the remnant nodules of material from which flakes were removed (e.g. van der Werf 2013). There are a few sites that have produced a moderate number of cores, such as 11 chert cores and two obsidian cores from Tac-Cawla, but compared to the 362 chert flakes, that is still not many (Malone et al.2020b). At Santa Verna, among hundreds of lithics, only a single core was recovered. Likewise, compared to many hundreds of flakes, only a single core, of supposedly imported chert, was found at Ta' Hagrat (Vella 2009). This paucity of cores suggests a spatial fragmentation of lithic reduction across the landscape, with cores removed from sites after flaking and/or primary flaking occurring at currently unknown localities and flakes being imported into the known sites. Aspects of spatial variability in the distribution of 
lithics can be also be observed at an intra-site level (e.g. Vella 2008a). While it therefore appears valid to describe a focus on rather amorphous, multidirectional, flake production, factors such as the paucity of cores which could add further information on core reduction methods, should be noted.

In terms of the retouched component, the central observation has been high levels of 'scraper' retouch (e.g. Ashby et al. 1913; Evans 1971; van der Werf 2013). Indeed, scrapers have been described as the "ubiquitous tool of Temple Period Malta" (Malone et al. 2009b, 243) (Fig. 2). Vella (e.g. 2008a, 2008b, 2011b) offered suggestions on the function of stone tools by looking at the shape of tools and the kind of retouch, with scrapers being for scraping and various other functional types linked to particular morphologies. Vella (2009) highlights some differences between sites, the meaning of which is currently unclear, such as Skorba scrapers typically only being retouched on one lateral edge, compared to commonly on two edges at $\mathrm{Ta}^{\prime} \mathrm{Hag}$ rat. It should be noted that a general trend in global lithic analysis has been the recognition of the complex relationship between form and function (see, for example Odell 2001; Andrefsky 2012; Douze et al. 2020), and so the notion that 'scrapers' are for 'scraping', for instance, should be seen as a hypothesis to be tested. Function is best clarified by usewear and residue analyses, rather than overall artefact morphology. When it comes to retouch in general, there is a conceptual ambiguity between retouch to influence the overall shape of a tool and retouch to specifically shape an edge. The notion of 'scraper' retouch could instead be seen as a focus on retouch of a medium steepness. This is a specific technological choice, as opposed to other options such as applying very steep retouch ('backing') to blunt an edge. In addition, very occasional other retouched forms such as apparent arrowheads have been found in Temple Period contexts in the Maltese islands (e.g. Evans,1971). While it is of course possible that some are intrusive, their genuine association seems most likely. This stands to the dominant 'scrapers' as the blade component does to the focus on flake production; as a seemingly somewhat exotic element.

While long distance import of exotic raw material such as obsidian has often been mentioned, it should be emphasised that these normally make up a small proportion of lithic assemblages. In the Neolithic Temple Period, obsidian typically makes up around 10-20\% of lithic assemblages by number (Malone et al. 2020b). It is, however, important to also consider the form in which obsidian occurs; mostly as very small flakes and fragments, perhaps suggesting intense reworking of a limited original supply of material. As noted by Vella (2008b) this implies that obsidian import was either irregular and/or controlled. The import of chert, from Sicily and perhaps mainland Italy, is again often mentioned. As discussed below, however there is often uncertainty about what is and is not imported as opposed to local chert. A cautionary warning here comes from the discovery that ochre at Maltese sites, long discussed as a supposedly key long-distance import (e.g. Robb 2001), is actually consistent with local sources (Attard Montalto et al.2012). While it is often unclear how large a proportion of each assemblage is made up of local chert, it is clearly extremely common, and yet little work has been done on describing its sources and characteristics from an archaeological perspective.

A final point which can be made in passing is that Maltese Neolithic lithic technology seems very distinct from that in Sicily, where forms such as backed blades, sickle-blades, and arrowheads are common (e.g. Nicoletti 1997). While this may partly reflect pragmatic aspects, such as raw material variation, this might also reflect social differentiation between the islands. 

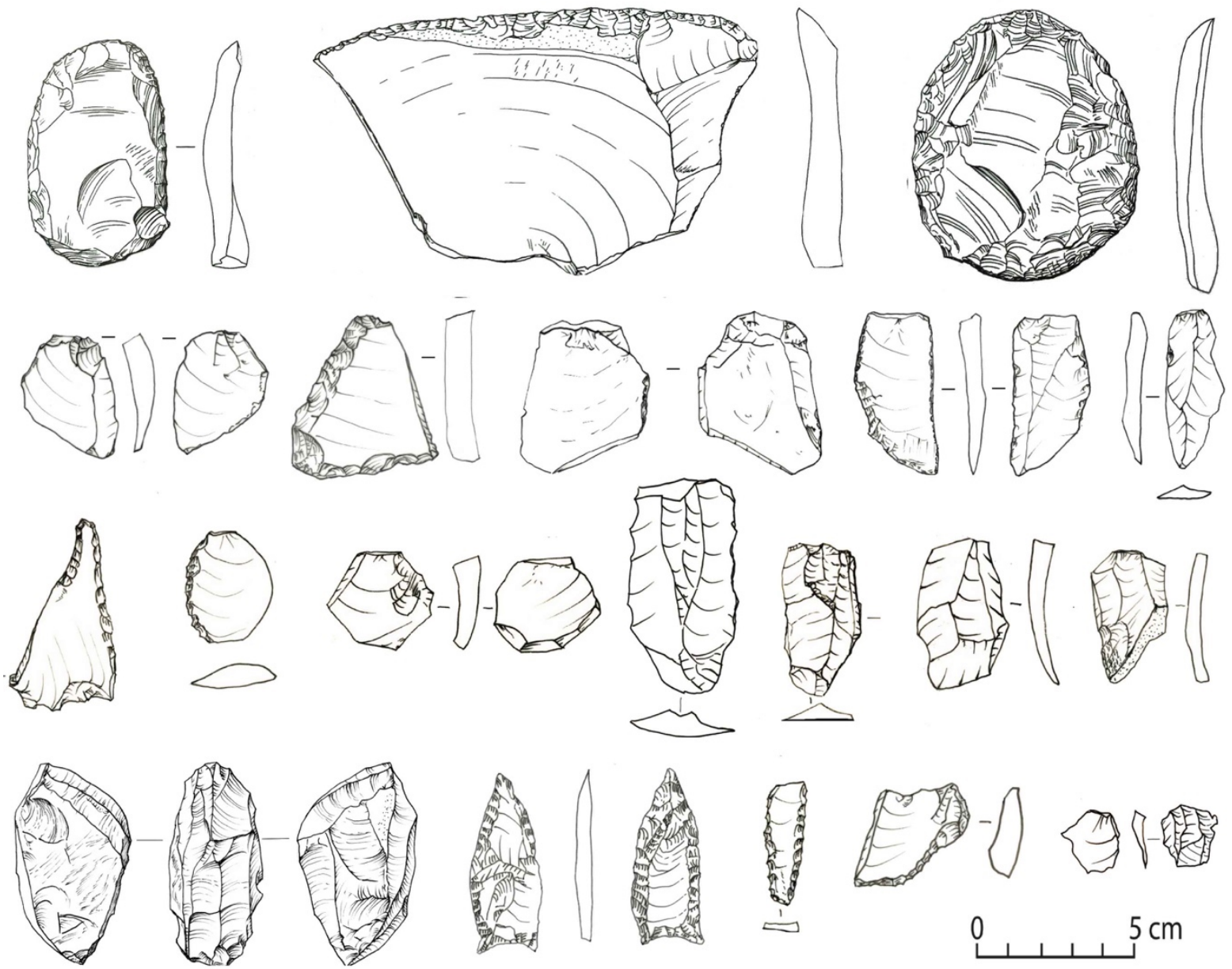

Figure 2. Examples of Maltese lithics from sites in Gozo and Malta. Top row: large scrapers on local chert from the Xagłra Circle (modified from Malone et al. 2009b). Second row: chert lithics from Santa Verna. Third row: chert lithics from Tać-Cawla. Bottom row: obsidian lithics from Tac-Cawla and Santa Verna. (Images reproduced from Malone et al. 2020b,c, CC-BYND license).

\section{Maltese chert geology and geochemistry}

The geology and landscapes of the Maltese islands have been described in detail by many authors (e.g. Felix 1973; Pedley et al. 1976, 1978, 2002; Baldassini and Di Stefano 2016; Gauci and Schembri 2019). In basic terms, the geological structure of the archipelago consists of a succession of marine sedimentary carbonates formed in the Oligocene and Miocene, approximately thirty to five million years ago (Fig. 1). The oldest is the Lower Coralline Limestone, a pale coloured and hard limestone that often forms spectacular coastal cliffs. This is overlain by the Globigerina Limestone. This is subdivided into yellow coloured Lower and Upper beds, and the white Middle Globigerina bed between them, in which chert occurs. Two phosphoritic conglomerate beds occur within the Globigerina, separating the three formations. This is overlain by the Blue Clay, a soft clay/marl layer. Finally, after a thin 'Greensand Formation' known for its abundant fossils, the sequence is topped by the Upper Coralline Limestone, similar in its characteristics to the Lower Limestone Formation. In summary, the Coralline Limestones represent shallow water conditions, with the Globigerina limestone between them representing deeper water, although with the latter interrupted by shallowing 
and strong current episodes indicated by the phosphoritic horizons. However, additional complexity comes from two factors. Firstly, tectonic activity has had a considerable impact on the islands, with some very dramatic faulting meaning abrupt changes in geology. Secondly, there is considerable lateral variability in the different beds of rock. This variability concerns both the thickness and subtle characteristics of the formations.

The Middle Globigerina (Kaћla or Turbazz in Maltese [Scerri 2019]), dating to about 16-20 million years ago, is the formation of most interest in the present context, given that it is the chert bearing formation in the Maltese islands (see e.g. Pedley et al. 2002; Bianco 2020). It is a white to grey coloured limestone, rich in planktonic foraminifera. It has long been known some there were chert outcrops in this formation (e.g. Cooke 1893). Further studies added detail on the chert deposits (e.g. Felix 1973). It is interesting to note that in studies such as these, even basic points such as the colour described for the chert are highly varied (see also e.g. Zammit 1930; Pedley et al. 1978; Sagona 2015 and others, who all describe the colour of the chert differently).
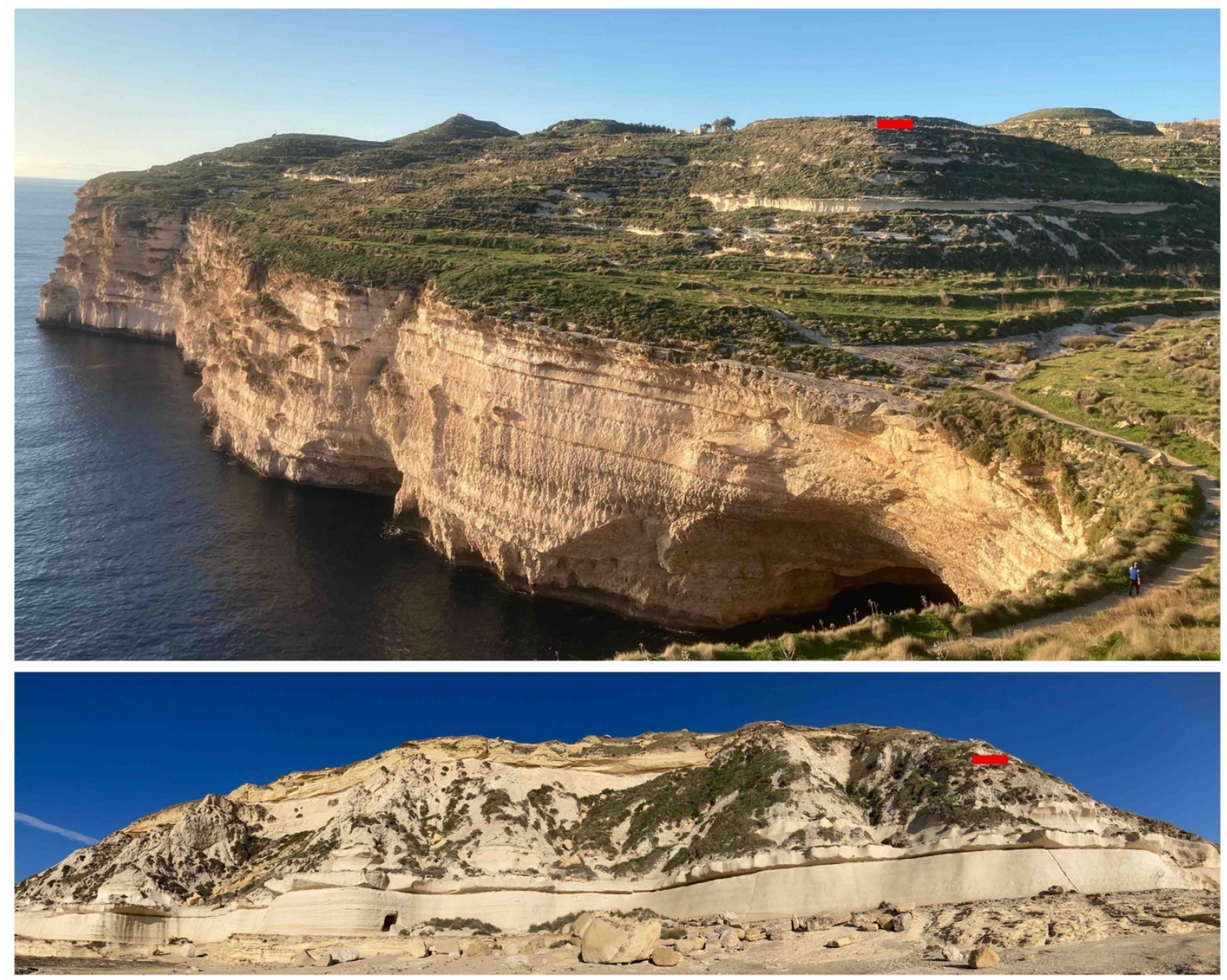

Figure 3. Two geological sections in western Malta, with red marker showing stratigraphic level of chert. Top, looking north at the point where Wied Ir-Rum meets the sea. Large sea cliff of Lower Coralline Limestone are Overlain by the Lower Globigerina Formation, visible as a distinct small yellow cliff. Above this is the Middle Globigerina Formation containing chert. Bottom: Il-Blata tal-Melh. Photo taken from Lower Coralline shore platform. Lower cliff is the Lower Globigerina Formation. Above it is the Middle Globigerina Formation, containing chert. Above this is the yellow-coloured Upper Globigerina Formation. 
Maltese chert has often been described as being low-quality, both in terms of how it can be knapped (e.g. Ashby et al. 1913, 49; Moscoloni and Vella 2012, 65 Sagona 2015, 31; Malone et al. 2009b, 242; Malone et al. 2020b, 406) and how it could be used, i.e. not being hard (Zammit 1930, 121). Specific technical points have been made on these issues, such as the suggestion by Ashby and colleagues $(1913,49)$ that Maltese chert is "ill adapted for flaking. In fracture it shows no bulb of percussion". As far as I'm aware though, no real knapping experiments have been conducted on Maltese chert. In contrast to the dominant notion of Maltese chert being low-quality, others have suggested a different perspective. Trump (2004, 240) described Maltese chert as "good", and "only slightly inferior to flint" (p. 17). To him, this is a key argument against their being early (i.e. pre-Neolithic) humans in Malta, as given the apparently good chert available in the islands, stone tools of any early people would surely have been found. Likewise, Ferguson (1991 p. 18), argued that the chert was of "satisfactory quality", with Vella (2011a) likewise choosing a middle ground, describing Maltese chert as "medium quality". In terms of the distribution of chert, Vella $(2009,2011)$ reports chert as occurring below Qleghja Hill (just south of Ras ir-Raheb), in the Fomm ir-Rih bay, and at Gnejna. Chatzimpaloglou (2019) suggested that in Malta chert was mostly found around Fomm ir-Riћ.

The recent work of Chatzimpaloglou (2019, 2020; Chatzimpaloglou et al. 2020a,b) has added valuable geochemical data on Maltese chert. This provides an explanation for the apparently 'low-quality' nature of Maltese chert; as these studies showed that the chert contains high levels of soft opal, rather than quartz, the hard, crystalline form of silicone dioxide. Chatzimpaloglou (2019, 2020; Chatzimpaloglou et al., 2020a, b) added further information on Maltese chert sources at Fomm ir-Rih in Malta and Dwerja in Gozo. Using a variety of analytical technique, they describe the variability of chert at these localities and from Maltese archaeological sites. This suggested factors such as high levels of variability in the amount of silicon dioxide they contain, as well as trace element characteristics which they use to suggest that some chert samples show a Sicilian origin. Many samples, however, remain of unclear provenance, not matching either known Maltese nor Sicilian sources. Interestingly, Chatzimpaloglou (2019) reported a previously unknown kind of chert from near Dwerja in Gozo, where fine-grained translucent white chert was identified. This suggests higher levels of variability in local chert characteristics than previously known. Chatzimpaloglou (2019) also suggested that small white spots are the "trademark of the Maltese chert" $(2019,209)$.

\section{Methods}

The aims of this study were two-fold; firstly, field survey was conducted to explore the distribution of chert outcrops and evaluate their character and, secondly, knapping experiments were conducted to elucidate the characteristics of Maltese chert.

In terms of distribution, several areas of Malta where the Middle Globigerina Formation is present were visited for pedestrian survey; namely Delimara Point, the Selmun Peninsula, and Qammieh. The key area for focus though was from Fomm ir-Rih southwards along the west coast, with the furthest point studied at $35.866910 \mathrm{~N}, 14.357428$ E. South of this point, the Middle Globigerina formation is present, but access is challenging. As an additional component of this study, a locality at the far eastern end of the Marfa ridge was visited. This had been identified by Prof. Chris Hunt. He had found some possible flakes, but it was unclear if they were lithic artefacts or geofacts (i.e. rocks produced by natural processes or actions such as ploughing, which can resemble purposeful lithics). 
During the survey, where outcrops were identified they were photographed and notes taken. The aim was not to systematically identify and report all chert outcrops, but to explore the spatial distribution at a landscape scale and gain insights into the kind of range of variability of these chert outcrops.

To evaluate the characteristics of the chert from an archaeological/lithic technology perspective, pieces of chert were collected for knapping experiments. Tabular chert was from collected from Fomm ir-Riћ and just south of Migira l-Ferha. Nodular chert was from Migra 1Ferha. Knapping was done by the author, using hard hammer stones (coralline limestone, quartzite).

\section{Description of chert sources}

Confirming early reports (e.g. Chatzimpaloglou 2019), chert was not identified away from the west coast of Malta, e.g. none was identified in the Middle Globigerina at Delimara, the Selmun Peninsula, and Qammieh. There should be a caveat here that some areas are intensely developed, and access is often challenging in heavily agricultural areas. The major finding in terms of the distribution of chert is that outcrops continue for several kilometres south of the Fomm ir-Riћ/ Ras ir-Raћeb area that has been emphasised in recent studies. This wider distribution was hinted at in earlier work (Felix 1973), but not discussed in more recent studies.

In terms of overall landscape characteristics, it is important to emphasize that most of these chert outcrops occur in rdum settings, i.e. on the steeply sloping land that occurs above the Lower Coralline Limestone, which form cliffs down to the sea level in this part of western Malta, and below the Upper Coralline Limestone which forms an upper-level escarpment. The rdum, between the Coralline formations, consists of the Globigerina and Blue Clay Formations. The latter often drapes the underlying Globigerina beds, as does scree and boulder material fallen from the Upper Coralline Limestone. An example of this rdum landscape which characterizes the western coast is shown in figure 4. Given that chert has a narrow exposure, in the Middle Globigerina Formation, this topography and geological sequence mean that it is often physically challenging to access possible chert sources, and that in many cases they are buried. A second factor is that extensive terracing has transformed the landscape of the area (e.g. fig. 4). Again, given the limited size of chert outcrops, one or two terraces could completely hide a chert source. A point that can be mentioned here, though, is that in my experience wherever chert is to be found in the bedrock, small pieces occur downslope, giving good clues as to what will be found upslope.

There is, however considerable variability in this landscape. In some places (fig. 3) the Middle Globigerina limestone occurs as a cliff or very steep terrain, and chert outcrops are located high up in hard to access settings. In other places the Globigerina beds are less steep than in rdum or cliff settings (e.g. fig. 7). Some of the prominent chert sources - such as at Fomm ir-Rih and Wied Ir-Rum - occur where faulting and valleys interrupt the steep terrain typical of the west coast. In both cases the chert is relatively accessible.

Beyond these general points, some more specific points can be made. Moving south from Ras ir-Raћeb, small paths lead over steep terrain and reveal chert sources continuing to the south. Outcrops were examined at several points, with variable fracturing and other characteristics. An example is shown in figure 5. To the south, towards Il-Blata tal-Melh, the slant of the land/bedrock means that the chert layers gradually become higher in a cliff face, and therefore hard to access. Some 'typical' characteristics can be seen here though. For instance, at 
$35.900238 \mathrm{~N}, 14.331159 \mathrm{E}$ where it is possible to, with caution, scramble up the steep slope, nodular chert occurs lower down and tabular chert higher up. This is the predominant pattern seen across the study area. The nodular chert typically occurs as small nodules, while the tabular chert often forms retreating exposures such as that shown in figure 5, with large numbers of broken chert fragments immediately underneath. Towards Il-Blata tal-Melh, the chert outcrops themselves were not accessed, but could be seen high above in the cliffs, and the ground surface below the cliffs has abundant chert fragments (see fig. 6).

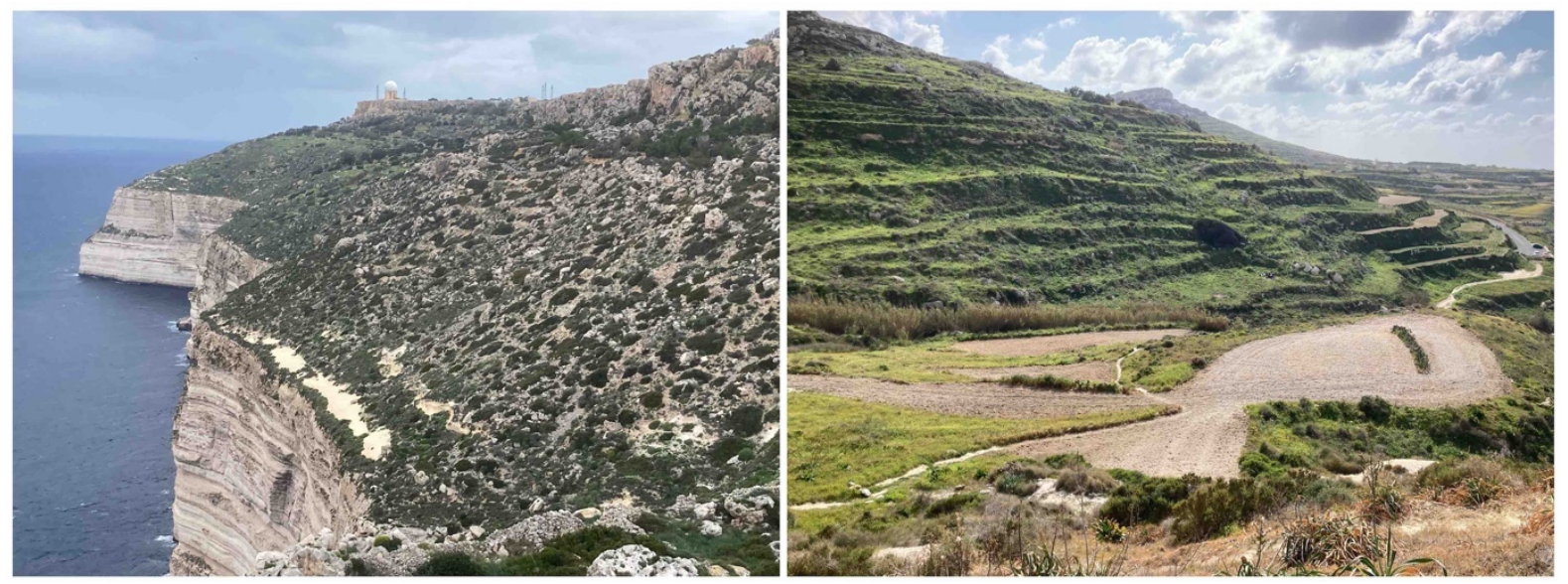

Figure 4. Two examples of typical scenery on the west coast of Malta. Left: steep rdum terrain near Dingli. Note Lower and Upper Coralline limestone cliffs, and considerable amount of scree and colluvium draping the Globigerina Formation. Right: Highly terraced landscape at Fomm ir-Riћ. A chert outcrop shown in figure 6 is located beside the path in the centre of the image.
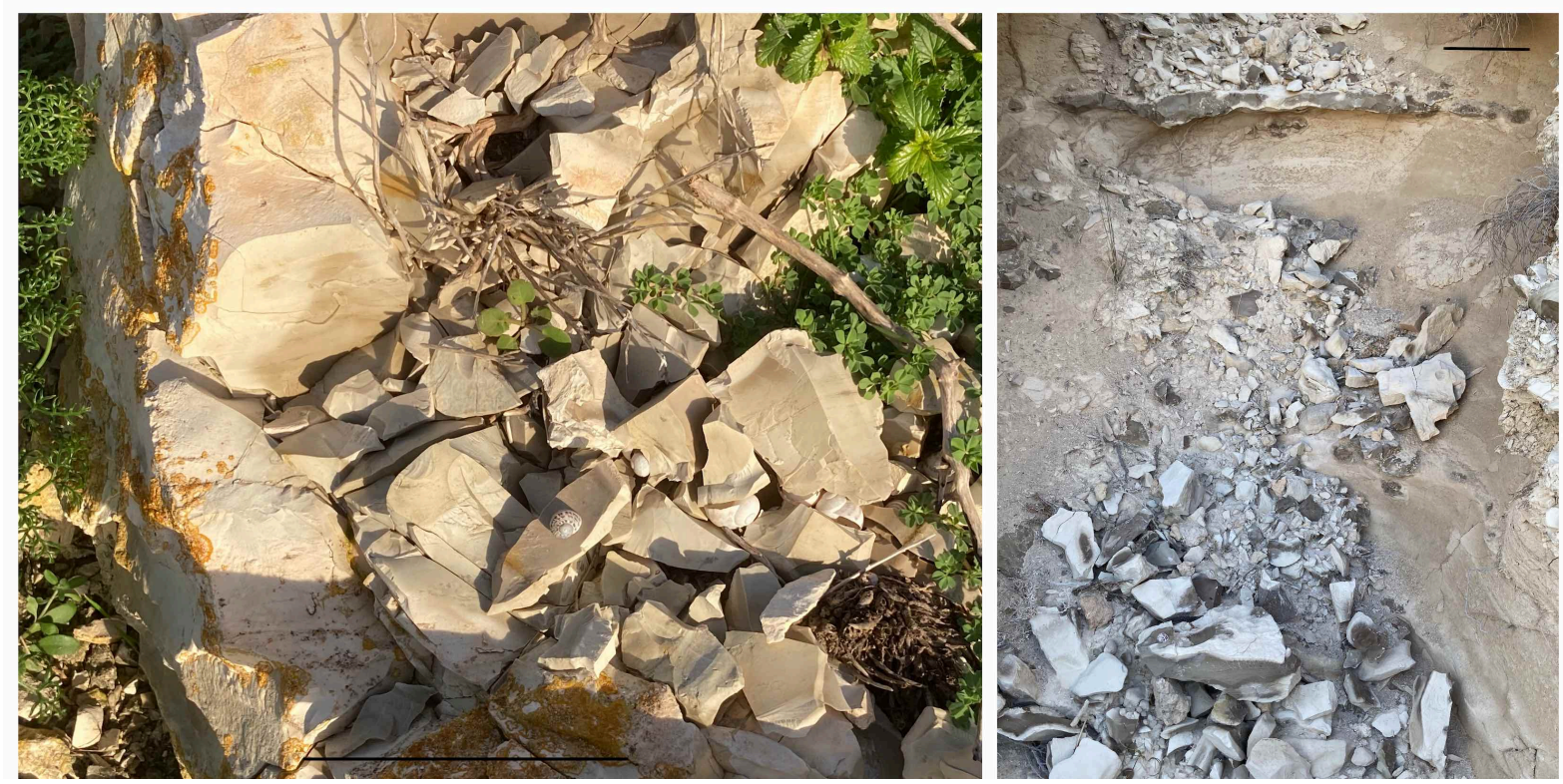

Figure 5. Examples of chert outcrops on west coast of Malta. Right: just south of Migira 1Ferha. Left: just south of Ras ir-Raћeb. Black scale bar: $10 \mathrm{~cm}$. 

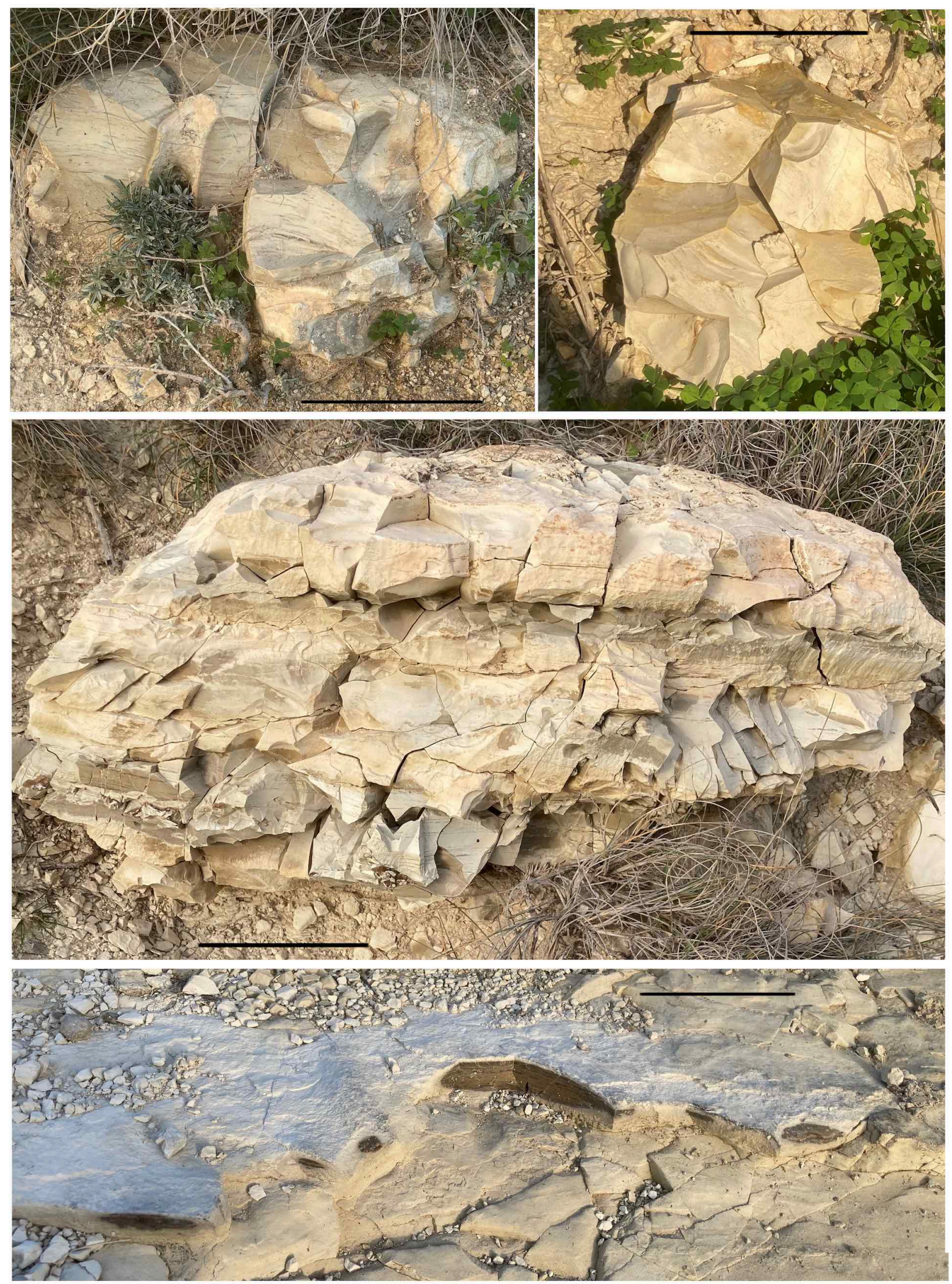

Figure 6. Further examples of chert outcrops (scale bar $=10 \mathrm{~cm}$ ). Clockwise from top left, 1) Ras ir-Raћeb, 2) eastern side Wied Ir Rum, 3) western side of Wied Ir Rum on edge of terraces on hill, 4) Migra l-Ferha on base of track. Note diversity of colours and textures, and frequent breakage into smaller nodules. Scale: $10 \mathrm{~cm}$. 
Moving south, chert outcrops were identified between Il-Blata tal-Melh and Migra 1-Ferha. At $35.883369 \mathrm{~N}, 14.338472 \mathrm{E}$, for instance, the chert shown in figure 8 is located, in a less steeply sloping rdum area than along much of this coast. This outcrop shows another form seen in several places, where a chert capping, and perhaps partial silicification of the underlying limestone, leaves 'tower-like' formations.

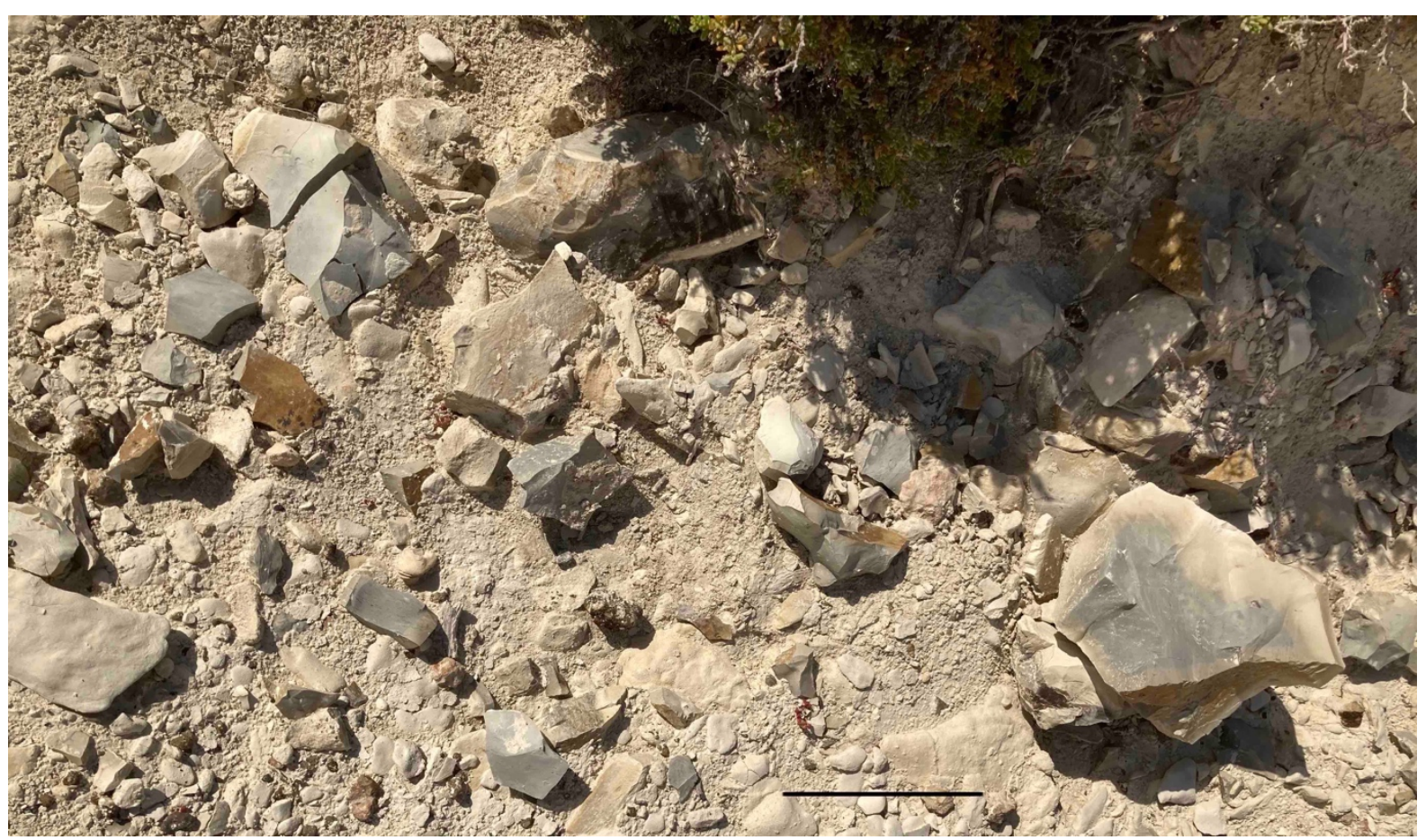

Figure 7. An example of profuse chert on the surface, below chert outcrops in cliff at Il-Blata tal-Melh. Scale: $10 \mathrm{~cm}$.

At Mig̀ra 1-Ferha, a track along the southern side of the valley to the east provides excellent exposures of chert. This track has been cleared, but not covered, and so provides a cross section through the Globigerina Formation. Here a thin brown bed of tabular chert is first observed (fig. 6). This shows that while in general the tabular forms are the upper chert deposits, this is not always the case. Following the track east (around $35.875973 \mathrm{~N}, 14.343813 \mathrm{E}$ ) nodular chert is next encountered, and then tabular chert, including in some large 'tower-like' masses. Back towards the coast, continuing south, chert can be observed in multiple places (for example at $35.873596 \mathrm{~N}, 14.345560 \mathrm{E})$. Some chert outcrops are profusely broken into angular chunks, which could potentially be mistaken for lithics in some cases, but lack eraillure scars and other such diagnostic features. The nodular chert occurs as both protrusions from rockfaces, and in more shattered forms where boulders have broken away from cliffs. An example of the nodular chert from just south of Migra 1-Ferha is shown in figure 9.

Continuing south, chert was found at several locations between Migra 1-Ferha and Ras idDawwara. For instance, at 35.872481 N, $14.346104 \mathrm{E}$, chert is found in an area of terraces. Here a sequence of (from the lowest) tabular to nodular to tabular can again be seen (the nodular bed here is shown in figure 6). An important observation here is that the top of the chert sequence (figure 10), in places light brown translucent chert occurs as a thin bed. This is a very fine-grained material, which is a matrix joining small angular chunks of limestone. Translucent chert has not previously been reported from Malta, and this finding joins the recent identification of white translucent chert in Gozo, discussed above. Chert continues to outcrop 
moving to the south, around the edge of the top of the terraced hill (e.g. at $35.871355 \mathrm{~N}$, 14.353265 E), as shown in figure 6.

Continuing south, the coastal escarpment is interrupted by a valley, Wied Ir Rum. Several chert sources are found in this area, and these are easily accessible as they found in the somewhat flatter terrain in the valley, compared to the sources found in the coastal rdum settings. Prominent chert outcrops, with lower nodular and upper tabular forms, can be found at 35.873371 N, 14.354419 E and 35.872256 N, 14.355294 E. In both cases, chert is both visible in the bedrock (figure 6) and as nodules on the ground. As well as at the outcrops themselves, chert fragments are found downslope in many places. This included one fragment of translucent fine-grained chert as a matrix holding together angular clasts (figure 10), similar to the previously described material from a bit further north.
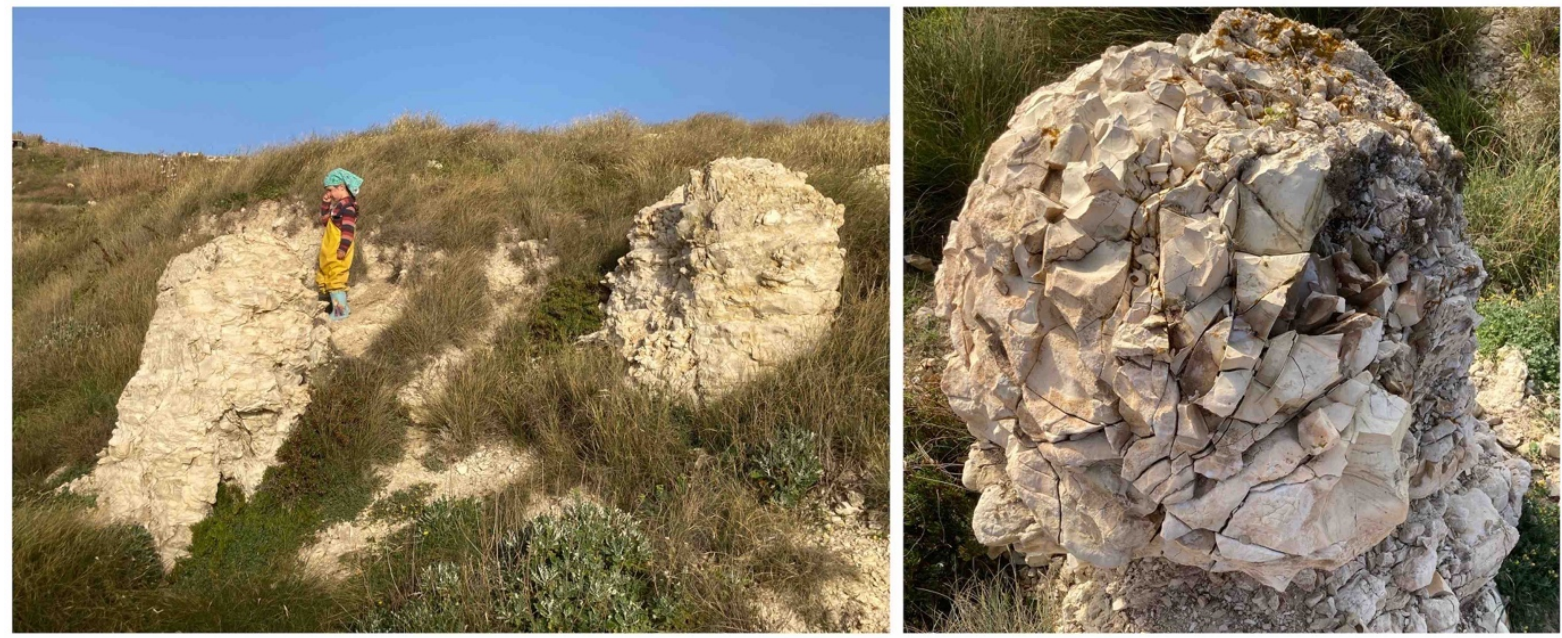

Figure 8. 'Tower-like' chert exposures, where a capping of fractured tabular chert prevents erosion of the underlying limestone, north of Migra 1-Ferha. Right images shows top down view of chert just in front of the person. Human scale: $107 \mathrm{~cm}$ high.
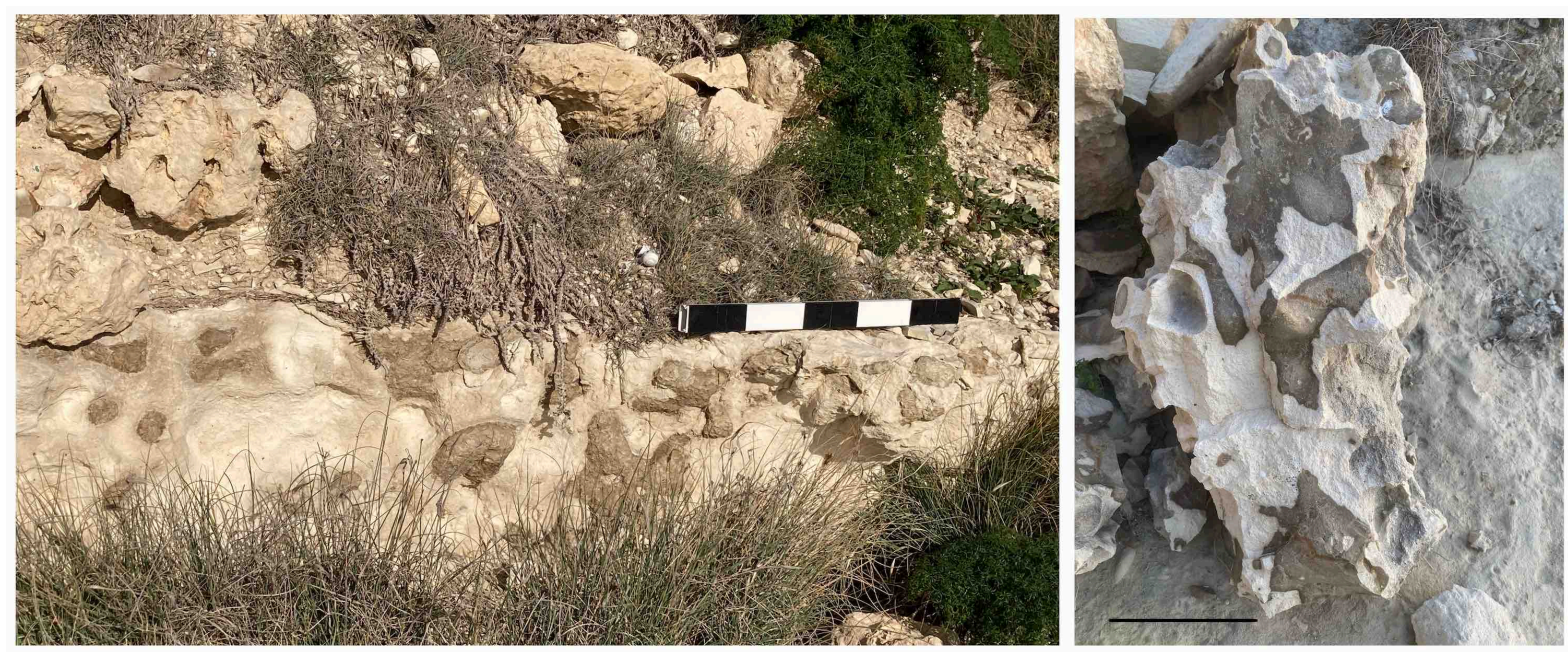

Figure 9. Nodular chert, left: between Migira 1-Ferha and Ras id-Dawwara, right: Migira 1Ferha. Scale bar on left: $50 \mathrm{~cm}$, on right: $10 \mathrm{~cm}$. 
Continuing south to Ras ad Dawwara, chert outcrops continue (for instance at $35.868274 \mathrm{~N}$, $14.355168 \mathrm{E}$ ). Once again, there is darker brown nodular chert beneath lighter coloured tabular chert. In this location, it looks possibly like the chert has been quarried, but it is hard to tell if digging was for some other purpose (terrace formation, stone quarrying, etc.). The furthest south chert source visited in this study was $35.866910 \mathrm{~N}, 14.357428 \mathrm{E}$. The chert presumably continues south, but in very steep terrain with a large sea cliff, and further south, around Dingli, ways down to the relevant locations to check for chert are gated shut.
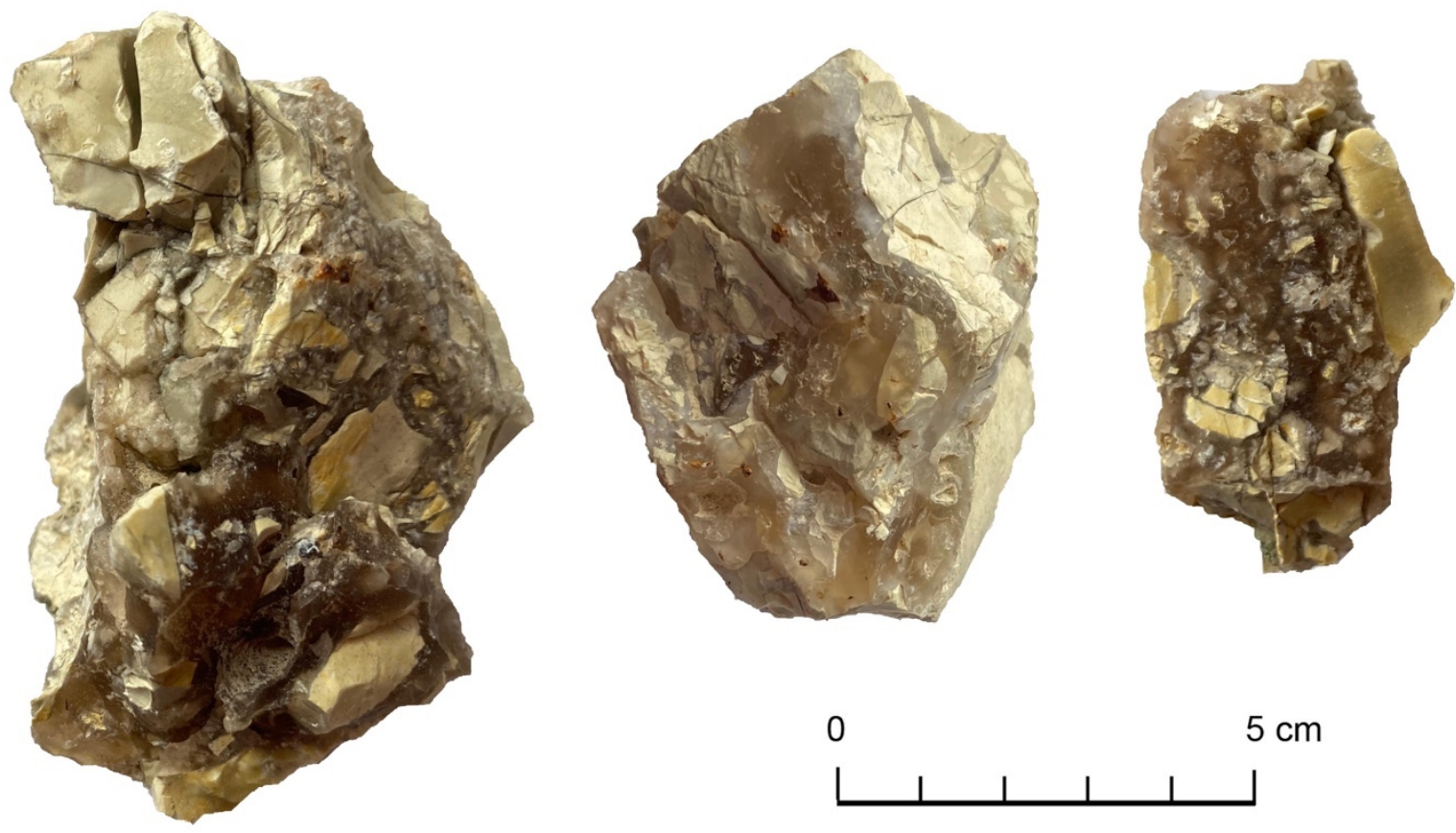

Figure 10. Examples of opaque fine-grained chert matrix, with abundant angular limestone clasts. From between Migra 1-Ferha and Ras id-Dawwara.

Some general observations can be made on the findings of the survey. The chert is quite varied in its colour and characteristics. While some examples feature the white spots described by Chatzimpaloglou (e.g. 2019) as being characteristic of Maltese chert, not all do. Chert at some outcrops seems to be more fractured than others, but a general point is that even where it occurs in large volumes, the chert is rather fractured, typically into relatively small chunks. The most prominent cherts are the lower brown nodules and the upper grey/brown tabular cherts, but there is added complexity in places, such as there sometimes being a basal tabular layer, and sometimes a translucent light brown capping.

Finally, the locality at the eastern end of Marfa ridge was visited (35.989479 N, 14.374572 E) The site is a flat area just inland from a steep cliff down to the sea, and is characterised by Upper Coralline Limestone. Upon visiting the site a few possible flakes were found on the surface, but these appear to be geofacts, or accidental flakes from spalling rock. There is a layer of rock which is perhaps more silicious than the rest of the coralline rock. This seemed to have formed a very subtle scarp which had been recently dug up to build dry stone walls in the immediately adjacent area. It seems that in the process of this, whether digging up the rock or shaping the rocks for the walls, a few 'flakes' were produced. A sample of the rock was collected for analysis. 

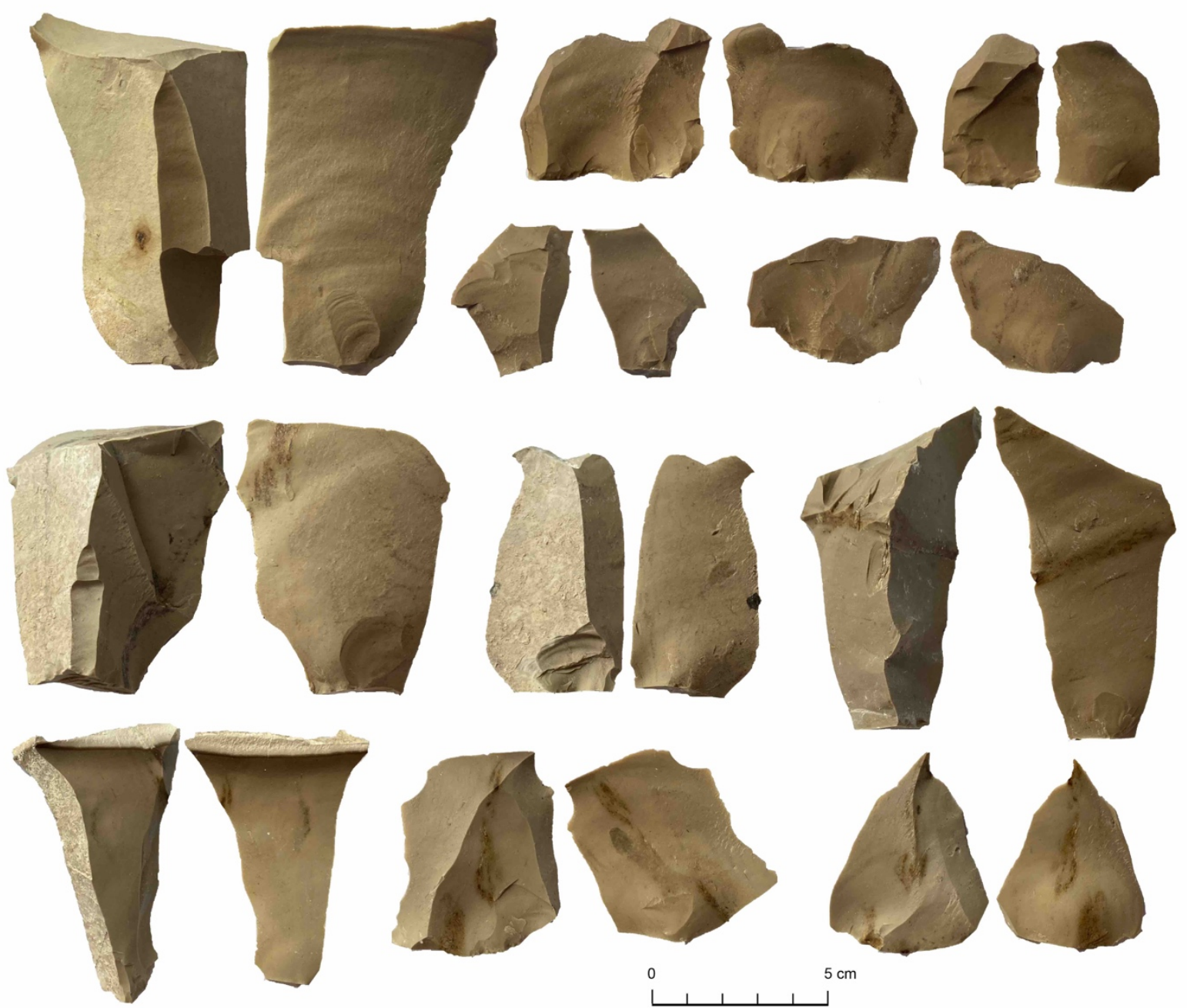

Figure 11. Flakes produced by hard hammer unidirectional reduction of chert from Fomm irRih, showing dorsal and ventral surfaces.

\section{Knapping experiments}

To evaluate the characteristics of the chert from an archaeological/lithic technology perspective, pieces of chert were knapped by the author, using a hard hammer technique. Hammer stones of both local coralline limestone and an imported quartzite pebble were effective at flaking the material.

Two reduction methods were used on the tabular chert. Firstly, a single-platform method to produce somewhat laminar debitage with unidirectional flaking was conducted on chert from Fomm ir-Rif. This was easy to achieve and shows that relatively elongated flakes can be made with this material. It is also clear that classic indications of knapping - such as ripples, bulbs of percussion, and eraillure scars are common with this material (Fig. 11). As mentioned earlier, Ashby et al. (1913) had suggested that Maltese chert did not form eraillure scars.

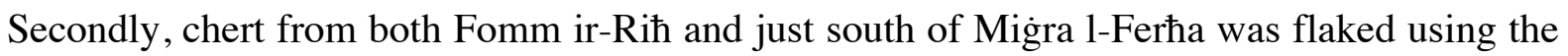
Levallois technique. Figure 12 shows the residual core and both sides of the Levallois flake produced from Fomm ir-Riћ chert. The core was flaked centripetally and the striking platform 
facetted. The large Levallois flake produced shows that large flakes like this can be produced with this chert. Figure 12 also shows a residual core and three Levallois flakes produced from it, primarily using unidirectional-convergent flaking, using chert from Migra l-Ferha. This was again easy to flake, and shows that several Levallois flakes can be produced from a relatively small original core.
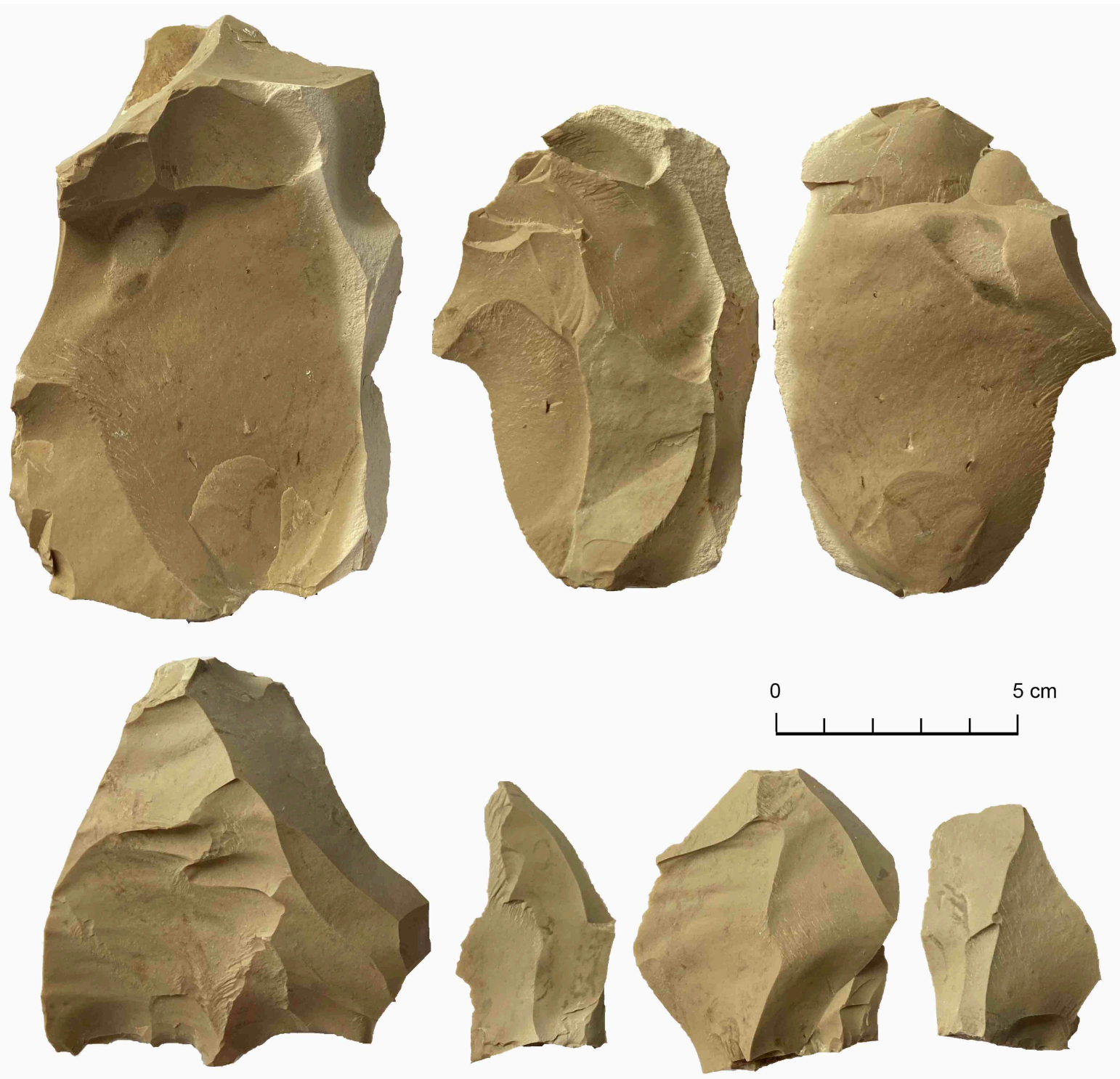

Figure 12. Two examples of hard-hammer reduction of Maltese chert using the Levallois method. Top: preferential Levallois core and refitting flake (left: dorsal, right: ventral) on Fomm ir-Riћ chert, with centripetal preparation. Bottom: residual core and three Levallois flakes produced from it using primarily unidirectional-convergent method, chert from Migra 1Ferћa. 

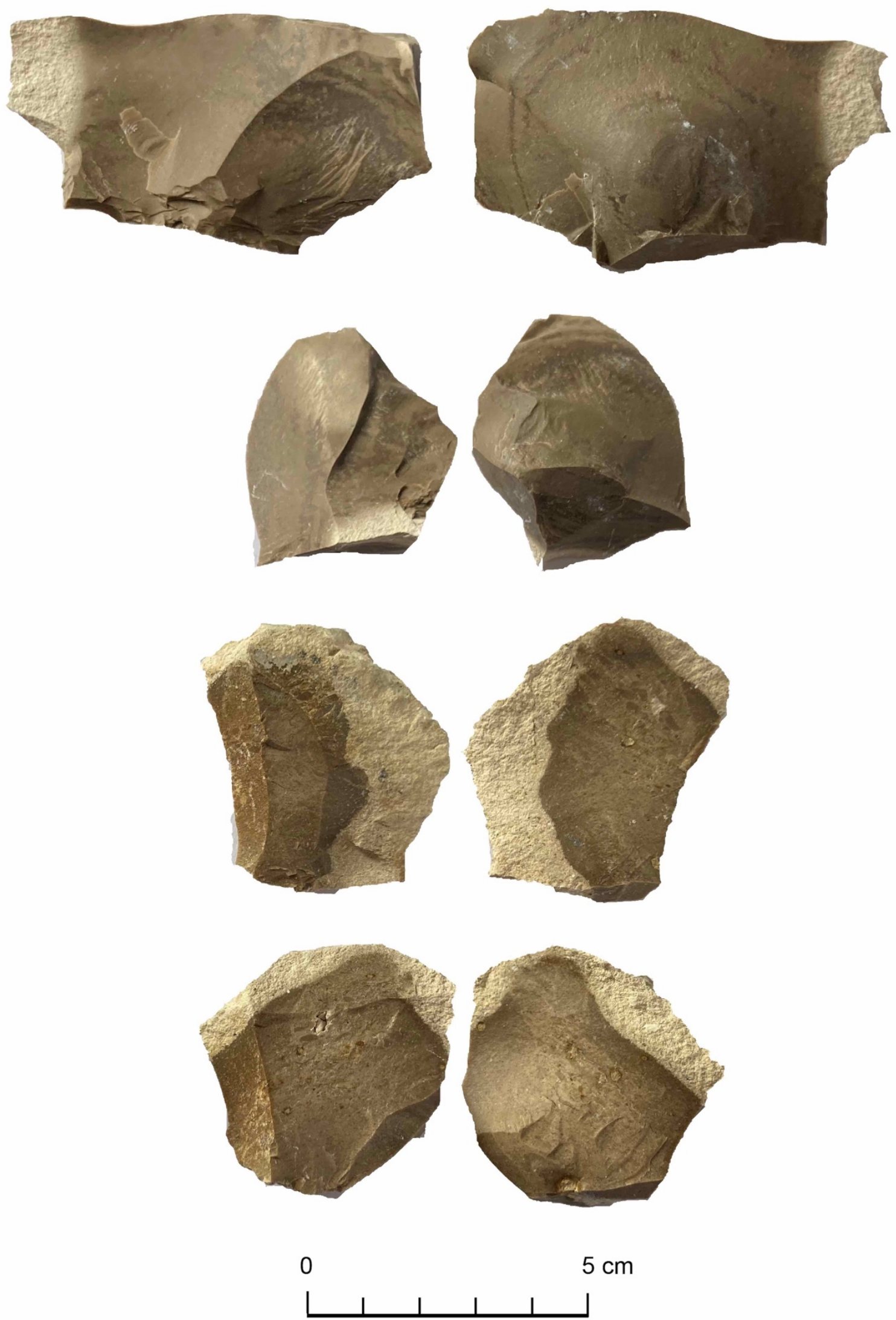

Figure 13. Examples of flakes produced on nodular chert from Migira 1-Ferha, showing dorsal and ventral surfaces. 
As a general point on the tabular chert, it is generally fairly homogenous and easy to flake. However, in some cases there are small internal flaws and fracture planes, and these subsequently interrupt flaking and prevent the production of long flakes. This seems to be more of an issue at some outcrops than others, and certainly encourages the knapper towards a more multidirectional approach as long unidirectional removals will often be impeded by the flaws. Often, when struck, a relatively large core will break into several pieces along these flaws and weaknesses. The material is then relatively homogenous, but the split cores are now relatively small, and so a focus on flake production is encouraged.

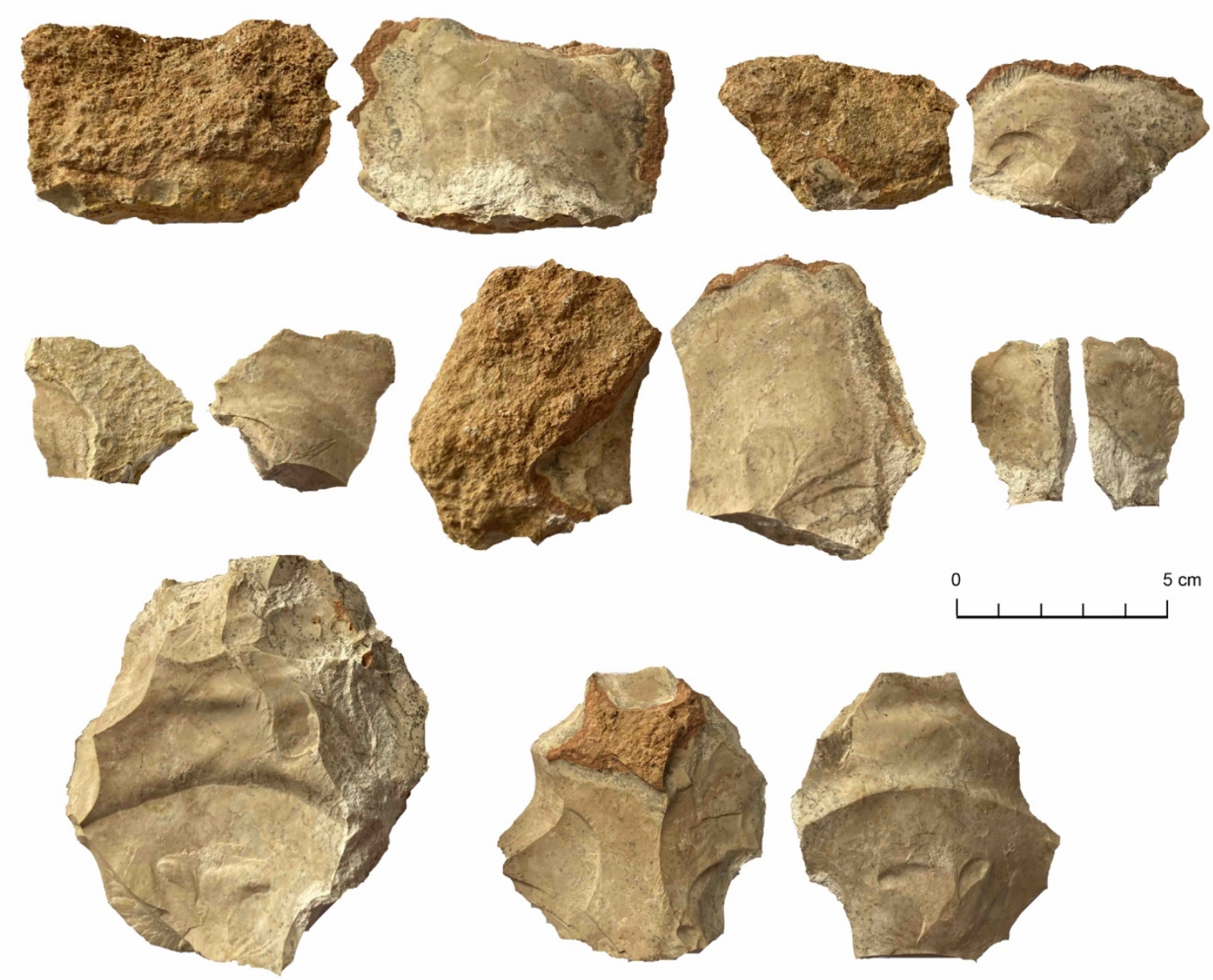

Figure 14. Products of Levallois reduction of Coralline Limestone from eastern end of Marfa ridge. Bottom left: core, showing centripetal preparation preferential removal. Bottom right, dorsal and ventral views of Levallois flake removed from core. Top: various preparation flakes, showing dorsal and ventral surfaces.

Next, the nodular chert was knapped. This occurs as relatively small nodules surrounded by limestone matrix. In some cases, upon flaking the chert separates entirely from the surrounding limestone, while in other cases flakes continue from the chert and into the limestone (e.g. fig. 13). The nodular material is also relatively easy to flake, but there is again an 'impetus' to multidirectional flake production from the character of the nodules.

While future studies will more formally examine the functional properties of Maltese chert lithics, it is fitting to make some basic points in passing. The edges of the chert flakes produced 
are not particularly sharp, and the edges are easily blunted by applying force on them against hard materials. Small flakes can be snapped by hand. The nodular chert feels harder and perhaps sharper than the tabular chert, although this impression needs to be formally tested in future. Compared to raw materials that the author has flaked from areas such as Southwest Asia and Britain, these characteristics of the Maltese chert are striking.

Finally, the Upper Coralline limestone from Marfa ridge was knapped. All the pieces shown in figure 14 were from a single block of rock. The cortex is very hard, and forceful blows were required to remove it. Flaking was easier on the more internal parts of the rock, and the material does conchoidally fracture. The nodule was shaped into a Levallois core with centripetal preparation, and a relatively large Levallois flake successfully removed. While not particularly sharp-edged, flakes from this material could seemingly be used for some tasks, and its hardness is interesting. Future studies should evaluate the Coralline Limestone formations for knappable materials.

\section{Discussion and conclusion}

While the long-distance transport of raw materials such as obsidian has featured prominently in discussions of Mediterranean prehistory, in areas such as the Maltese islands there remains a lack of certainty about which materials were imported and which weren't. Likewise, the implications of imports are unclear, with some authors suggesting that they demonstrate regular contact with areas such as Sicily, yet the available data also are also consistent with much more episodic contact.

Here it has been demonstrated that chert outcrops occur over a considerable distance of the west coast of Malta, at least five kilometres as the crow flies, more like ten $\mathrm{km}$ in reality, and possibly continuing further south. The characteristics of the chert have been described, such as it typically occurring in a very fractured form, such as that even a large outcrop of chert will consist of many small clasts. Along with other recent studies (e.g. Chatzimpaloglou 2019), these findings both describe the dominant trends observed, and highlight aspects of variation such as occasional examples of translucent chert being identified. Evaluating the macroscopic character of chert at the outcrops and of the knapping characteristics of the material bring some new perspectives to knowledge on Maltese lithic technology are brought forward.

The notion of lithic raw material 'quality' is complicated, as ease of manufacture and characteristics in terms of use are not the same thing (see also e.g. Groucutt et al. 2017). In terms of the act of flake production, Maltese chert is easy to flake. In some cases, however, flaws within the chert nodules mean initial cores break into smaller chunks, which encourages a more multidirectional kind of flake production. However, as the knapping experiments conducted show, both laminar flakes and Levallois flakes can be produced with Maltese chert. Arguably more pertinent in terms of quality is the character of the edges produced. These are generally not particularly sharp, and blunt very easily. Rather than a cultural preference for typological 'scrapers', this may explain the frequent use of 'scraper' retouch in Maltese assemblages. By applying semi-steep retouch the edges can be made much stronger than the natural margins produced by flaking.

In summary, the 'ad hoc' character of Maltese chert lithic assemblages may actually represent sensible adaptations to the characteristics of the local raw material. This can be evaluated 
through future formal experimental work, as can the extent to which chert was imported into the islands by continued geochemical analyses of diverse samples.

\section{Acknowledgements}

I thank Freda Scerri for assistance with the survey. I thank Eleanor Scerri, Nick Vella, Reuben Grima, Ian Candy, John Betts, Chris Hunt, and Ritienne Gauci for discussions on Maltese prehistory and geology.

\section{References}

Andrefsky, W.A. 2012. Lithic: Macroscopic Approaches to Analysis. Cambridge: Cambridge University Press.

Ashby, T., Bradley, R.N., Peet, T.E., Tagliaferro, N. 1913. Excavations in 1908-11 in various megalithic buildings in Malta and Gozo. Papers of the British School at Rome 6: 1-126.

Baldassini, N., Di Stefano, A. 2016. Stratigraphic features of the Maltese Archipelago: a synthesis. Natural Hazards 86: 203-231.

Bianco, L. 2020. Petrological, mineralogical and geochemical characteristics of the Globigerina limestone outcropping at Fomm Ir-Riћ, Malta. Competes Rendus de l'Académie bulgare des Sciences 73: 985-991.

Bonanno, A. 2017. The Archaeology of Malta and Gozo: 5000 BC-AD 1091. Malta: Heritage Malta.

Chatzimpaloglou, P. 2019. Geological reconnaissance and provenancing of potential Neolithic chert sources in the Maltese Islands. Unpublished PhD dissertation, University of Cambridge.

Chatzimpaloglou, P. 2020. A geoarchaeological methodology for sourcing chert artefacts in the Mediterranean region: A case study from Neolithic Skorba on Malta. Geoarchaeology 35: 897-920.

Chatzimpaloglou, P., Schembri, P.J., French, C., Ruffell, A., Stoddart, S. 2020. The geology, soils and present-day environment of Gozo and Malta, in C. French, C.O Hunt, R. Grima, R. McLaughlin, S. Stoddart, C. Malone (eds) Temple Landscapes. Fragility, change and resilience of Holocene environments in the Maltese Islands: 19-34. Cambridge: McDonald Institute Monographs, McDonald Institute for Archaeological Research.

Chatzimpaloglou, P., French, C., Pedley, M., Stoddart, S. 2020b. Connecting chert sources of Sicily with Neolithic chert artefacts of Malta. Journal of Archaeological Science 29: 102111.

Cooke, J.H. 1893. On the occurrence of concretionary masses of flint and chert in the Maltese limestones. Geological Magazine 10: 157-160. 
Douze, K., Igreja, M., Rots, V., Cnuts, D., Porraz, G. 2020. Technology and function of Middle Stone Age points. Insights from a combined approach at Bushman Rock Shelter, South Africa: 127-141, in H. Groucutt (ed) Culture History and Convergent Evolution. Cham, Springer.

Evans, J.D. 1971. The Prehistoric Antiquities of the Maltese Islands, a Survey. London: Athlone Press.

Felix, R. 1973. Oligo-Miocene stratigraphy of Malta and Gozo. Unpublished PhD dissertation, University of Utrecht.

Groucutt, H.S., Scerri, E.M.L., Amor, K., Shipton, C., Jennings, R.P., Parton, A., Clark-Balzan, L., Alsharekh, A., Petraglia, M.D. 2017. Middle Palaeolithic raw material procurement and early stage reduction at Jubbah, Saudi Arabia. Archaeological Research in Asia 9: 44-62.

Ferguson, I.F.G. 1991. The Temple Builders of Prehistoric Malta. Unpublished PhD dissertation, University of London.

French, C., Hunt, C.O., Grima, R., McLaughlin, R., Stoddart, S., Malone, C. (eds.). 2020. Temple Landscapes: Fragility, change and resilience of Holocene environments in the Maltese Islands. Cambridge: McDonald Institute for Archaeological Research.

Gauci, R., Schembri, J.A. (eds.). 2019. Landscapes and Landforms of the Maltese Islands. Cham: Springer.

Grima., R., Stoddart, S., Hunt, C.O., French, C., McLaughlin, R., Malone, C. 2020. Cultural landscapes in the changing environments from 6000 to 2000 BC, in C. French, C.O Hunt, R. Grima, R. McLaughlin, S. Stoddart, C. Malone (eds) Temple Landscapes. Fragility, change and resilience of Holocene environments in the Maltese Islands: 223-238. Cambridge: McDonald Institute Monographs, McDonald Institute for Archaeological Research.

Harmand, S., Lewis, J.E., Feibel, C.S., Lepre, C.J., Prat, S., et al. 2015. 3.3-million-year-old stone tools from Lomekwi 3, West Turkana, Kenya. Nature 521: 310-315.

Malone, C., Stoddart, S., Bonanno, A., Trump, D. (eds.). 2009a. Mortuary customs in prehistoric Malta: Excavations at the Brochtorff Circle at Xagћra (1987-1994). Cambridge: McDonald Institute for Archaeological Research.

Malone, C., Bonano, A., Trump, D., Dixon, J., Leighton, R., Pedley, M., Stoddart, S., Schembri, P.J. 2009b. Material Culture, in C. Malone, S. Stoddart, A. Bonano, D. Trump (eds) Mortuary Customs in prehistoric Malta. Excavations at the Brochtorff Circle at Xaghra (19871994): 219-314. Cambridge: McDonald Institute for Archaeological Research.

Malone, C., Grima, R., McLaughlin, R., Parkinson, E.W., Stoddart, S., Vella, V. (eds.). 2020a. Temple Places: Excavating cultural sustainably in prehistoric Malta. Cambridge: McDonald Institute for Archaeological Research.

Malone, C., Chatzimpaloglou, P., Brogan, C. 2020b. Small finds and lithics: Reassessing the excavated artefacts and their sources in prehistoric Malta, in C. Malone, R. Grima, R. McLaughlin, E.W. Parkinson, S. Stoddart, N. Vella (eds) Temple Places: Excavating cultural 
sustainably in prehistoric Malta: 399-446. Cambridge: McDonald Institute for Archaeological Research.

Malone., C., McLaughlin., Armstrong, S., Bennett, J., McAdams, C., French, c., Stoddart, S., Cutajar, N. 2020c. Excavations at Tac்-Cawla, Gozo, 2014, in C. Malone, R. Grima, R. McLaughlin, E.W. Parkinson, S. Stoddart, N. Vella (eds) Temple Places: Excavating cultural sustainably in prehistoric Malta: 39-122. Cambridge: McDonald Institute for Archaeological Research.

Moscoloni, M., Vella, C. 2012. The Tas-Silg lithic assemblage: preliminary observations on lithic typology and technological choices from the 2003-2010 seasons. Scienze Dell' Antichità 18: $65-81$.

Murray, J. 1890. The Maltese Islands, with special reference to their geological structure. Scottish Geographical Magazine 6: 449-488.

Nicoletti, F. 1997. Le industries litiche oloceniche: forme, materie prime e aspetti economici, in R. Leighton (ed) Early Societies in Sicily, New developments in archaeological research, specialist studies on Italy: 58-69. London: Aconnia.

Odell, G.H. 2001. Stone tool classification at the End of the Millennium: Classification, Function, and Behavior. Journal of Archaeological Research 9: 45-100.

Pace, A. 2004. The sites, in D. Cilia (ed) Malta Before History: 43-227. Malta: Miranda.

Pedley, H.M., House, M.R., Waugh, B. 1976. The geology of Malta and Gozo. Proceedings of the Geologists’ Association 87: 325-341.

Pedley, H.M., House, M.R., Waugh, B. 1978) The geology of the Pelagian Block: The Maltese Islands, in A.E.M. Nairn, W.H. Kanes, F.G. Stehli (eds) The Ocean Basins and Margins 4B, The Western Mediterranean: 417-433. London: Plenum.

Pedly, M., Hughes Clarke, M., Galea, P. 2002. Limestone Isles in a Crystal Sea. The Geology of the Maltese Islands. San Gwann: Publishers Enterprise Group

Renfrew, C. 2004. Foreword, in D. Cilia (ed), Malta Before History: 10-12. Malta: Miranda.

Sagona, C. 2015. The Archaeology of Malta: from the Neolithic through the Roman period. Cambridge: Cambridge University Press.

Scerri, S. 2019. Sedimentary evolution and resultant geological landscapes, in R. Gauci, J.A. Schembri (eds) Landscapes and Landforms of the Maltese Islands: 31-48. Cham: Springer.

Skeates, R. 2008. Making sense of the Maltese Temple Period: An archaeology of sensory experience and perception, time and mind. The Journal of Archaeology, Consciousness and Culture 1: 207-238.

Trump, D. 1966. Skorba. Excavations carried out on behalf of the National Museum of Malta, 1961-1963. (Research Report of the Society of Antiquaries of London 22). London: Society of Antiquaries. 
Trump, D. 2002. Malta: Prehistory and Temples. Santa Venera: Midsea Books.

Trump, D. 2004. Dating Malta's prehistory, in D. Cilia (ed) Malta Before History: 230-231. Malta: Miranda.

Van der Werf, V. 2013. In the Shadow of Megaliths: the forgotten tools and implements from Malta's prehistoric Temples. A material study and contextual approach to the Neolithic Temples of Tarxien, Malta, 3600-2400 BC. Unpublished bachelors dissertation, University of Leiden.

Vella, C. 2008a. Distribution patterns of imported lithic tools in Early Neolithic Skorba. Distribution patterns of imported lithic tools in Early Neolithic Skorba, in M. Zammit, J. Mallia (eds) Ta'Hagrat and Skorba: Ancient Monuments in a Modern World: 75-86. Gudja: Heritage Malta.

Vella, C. 2008b. Report on the lithic tools of Sicilian origin from the prehistoric site of Skorba, Malta, in A. Bonano (ed) Malta and Sicily: Miscellaneous Research Projects: 1-50. Palermo: Officina di Study Medievali.

Vella, C. 2009. The lithic toolkit of Late Neolithic Ta'Hagrat, Malta. Origini: 85-102.

Vella, C. 2011a, in D. Tanasi, C. Vella (eds) Site, Artefacts and landscape-Prehistoric Bor $\dot{g}$ in-Nadur, Malta: 173-194. Monza, Polimetrica.

Vella, C. 2011b. The lithic assemblage of the promontory site at Ras Il-Pellegrin. Traces in Time 1: 1-24.

Vella, C. 2016. Manipulated connectivity in island isolation: Maltese prehistoric stone tool technology and procurement strategies across the fourth and third millenia BC. The journal of Island and Coastal Archaeology 11: 344-63.

Zammit, T. 1930. Prehistoric Malta, The Tarxien Temples. Oxford: Oxford University Press.

Huw Groucutt is Max Planck Society group leader (W2) of the Extreme Events Research Group, in Jena, Germany. He has an undergraduate degree in archaeology and masters degree in palaeoanthropology from the University of Sheffield, and a D.Phil. in archaeological science from the University of Oxford. He specialises in the study of human prehistory, particularly from the perspective of stone tool technology, in Southwest Asia, the Mediterranean, and Africa. He is involved in a variety of fieldwork and analytical projects. 